\title{
Decoding High-K Rocks: Linking Magma Source and Metal Endowment
}

\author{
ANTHONY W. LANATI* AND STEPHEN F. FOLEY \\ Department of Earth and Environmental Sciences and ARC \\ Centre of Excellence for Core to Crust Fluid Systems, \\ Macquarie University, Sydney, Australia. \\ (* correspondence: anthony.lanati@mq.edu.au)
}

High-K magmas, including shoshonites and leucitites have been described, studied and variously classified for well in excess of 100 years. Despite this, there is still little understanding of the processes governing their formation and the controls on metal enrichment within some of these magmas. Globally, high-K volcanic rocks are generally explained as the result of low-degree partial melting from a peridotitic mantle source, with $\mathrm{K}$ usually being coupled with $\mathrm{H} 2 \mathrm{O}$ in volatile-rich magmas. However, it is becoming increasingly apparent that mica and pyroxene-rich ultramafic rocks are more widespread in the mantle than previously thought, and that mica-rich sources are much more efficient generators of high-K melts than the classic peridotite source.

We have taken a data-based approach to evaluate the source(s) of potassic magmas from a wide range of tectonic settings. Our approach uses sequential chemical screening of shoshonitic and leucititic samples from the GeoRoc Database. Screening considers all magmas with $\mathrm{SiO} 2<70 \mathrm{wt} \%$ in combination with the IUGS classification of $\mathrm{K} 2 \mathrm{O} / \mathrm{Na} 2 \mathrm{O}=$ $0.5-2$ and the Wheller classification ${ }^{1}$ of leucitites $(\mathrm{K} 2 \mathrm{O} \geq 0.4$ - $\mathrm{SiO} 2$ - 15.6) as starting points. We do not use the IUGS $\mathrm{SiO} 2$ screens for shoshonites $(50-57 \mathrm{wt} \%)$, allowing us to investigate source relationships between magma types without eliminating samples. Once filtered, data are examined in TAS, $\mathrm{K} 2 \mathrm{O}$ vs. $\mathrm{Na} 2 \mathrm{O}, \mathrm{K} 2 \mathrm{O}$ vs $\mathrm{SiO} 2$ space, and trace elements.

This review compares major element associations and trace element patterns between ostensibly similar high-K rocks from various tectonic settings. We assess the similarities and differences between rock types (leucitites, shoshonites and lamprophyres), and the implications these have for genetic associations. This approach permits us to elucidate differences in terms of source mineralogy and rock type, tectonic setting, and potential for critical metal endowment.

1: Wheller, G.E., Varne, R., Foden, J.D., Abbott, M.J. (1987) J. Volc. Geotherm. Res. 32, 137-160. 